\title{
The Importance of Alternative Solar Energy Sources and the Advantages and Disadvantages of Using Solar Panels in this Process
}

\author{
Tulakov Jakhongir Turakul Ugli \\ Department of Electric Power Industry, Faculty of Electromechanics and Radioelectronics, Jizzakh Polytecnic Institute, Jizzakh, Uzbekistan
}

\section{Email address:}

goodluck_0714@mail.ru

\section{To cite this article:}

Tulakov Jakhongir Turakul Ugli. The Importance of Alternative Solar Energy Sources and the Advantages and Disadvantages of Using Solar Panels in this Process. American Journal of Software Engineering and Applications. Vol. 8, No. 1, 2019, pp. 32-35.

doi: 10.11648/j.ajsea.20190801.14

Received: February 19, 2019; Accepted: March 28, 2019; Published: August 16, 2019

\begin{abstract}
This article reviews and analyzes the advantages and disadvantages of alternative solar energy and the use of solar panels in this process. The solar energy that is falling on the photoelements under a certain angle depends on environmental climax, season, and location. Atmospheric changes also lead to changes in the transverse and direct rays of light, which does not change the light, spectrum and intensity of falling light. These changes will change the principle of operation of the QES. Also, suggestions and recommendations regarding the risks of using solar panels are provided. Moto electric devices work full time in the morning and in the evening at low power. But the highest power supply is late at night. In addition, the energy generated dramatically changes rapidly due to weather changes. In order to eliminate these shortcomings, the AES uses electric accumulators, or it can be used to transfer energy to other types of energy, and it is also used for hydraulic accumulator stations or hydrogen power. At present, the problem is solved by building a common energy system.
\end{abstract}

Keywords: Alternative Energy, Solar Panels, Atmosphere, Photoelectric Elements, Photoconductor Devices

\section{Introduction}

Solar Energy-The direction of non-energized energy is based on the use of solar radiation and solar energy in different types. Solar energy is an endless source of energy, which is ecologically clean and is not considered harmful. Solar energy can be generated from special QESs. [1]

In order to convert solar spectra into useful energy, there must be land plots for special power plants using the 1 st and 2nd generation photovoltaic cells. For example, about 1 square kilometer area is required to build a $1 \mathrm{Gvt}$ power plant. However, microclimate changes can be observed in the same area after the QES has been made. Therefore, 1/2 MW photovoltaic power stations can be installed separately and individually. Photoelectric elements of large KES are installed at a height of $1.8-2.5$ meters. The reason for this is the use of agricultural land and animal husbandry.

Some of the HPPs are exposed to problems with weather conditions and the length of the day, and solar aerostatics are used to address these problems. a) The prices of these photos are very high, and their cost has dropped from $4 \%$ in 1990 to 2005 .

b) The surfaces of the photopanels and mirror photovoltaic should always be cleaned of different dust. Certain large areas of the solar photovoltaic station, some of which are several kilimeters, can be a challenge for cleaning. But this problem is being solved because modern solar cells are polished on the mirror surface.

c) The effectiveness of photovoltaic plants heating will be reduced. So they are equipped with a cooling system. In the production of photovoltaic products, the damage does not exceed the level of damage. The duration of the modern photovoltaic can range from 30 to 50 years. Cadmium is used for high efficiency of some photovoltaics, and no ecologically acceptable measures have been taken to utilize cadmium that has expired. Cadymi has been able to use other elements instead. At present there is a production of photovoltaic films with $1 \%$ silicon. [2] Therefore, these silicon cameras are widely used in industry. But because of the effectiveness and degradation of these photovoltaics, 
there are certain disadvantages. Solar concentrators can alter the properties of the Earth and change its plants. The growth of the solar cells' air, the air is associated with the reflection of the Sun's light. This phenomenon can change the humidity, heat balance and direction of the wind. Low-temperature boiling fluids in solar panels can be exposed to drinking water after a long period of use.

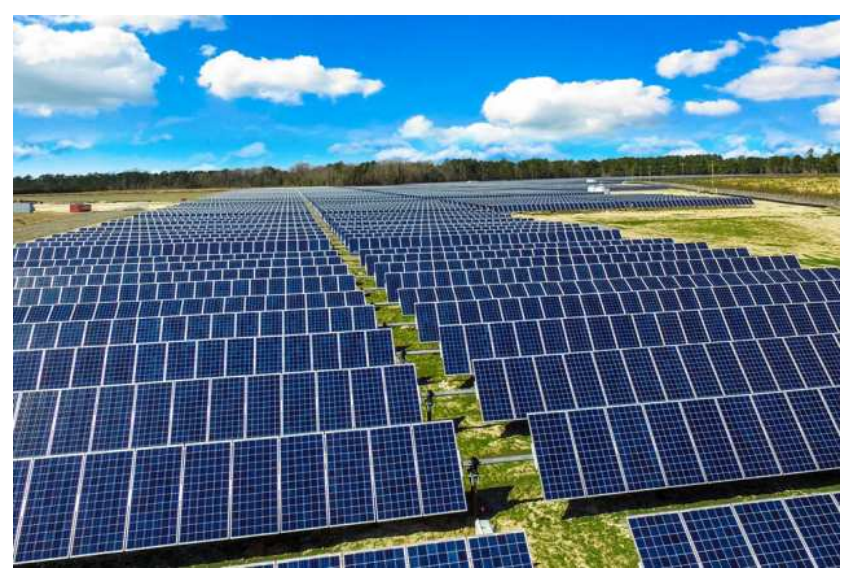

Figure 1. Example of solar energy [3].

By 2050, human beings receive $20-25 \%$ of the sun's electricity. According to international energy experts, in 40 years, with the help of modern technology, it produces 9,000 TEUs of energy or 20 to 25 percent of electricity per hour, which in turn reduces the $\mathrm{CO}_{2}$ emissions by about 6 billion tons. But after 40 years, the global energy crisis can not stop it. The importance of solar energy in this regard is not high. The principle of operation of all the industries and the elements of the electrical element is not working without the use of carbon dioxide. But solar energy is only about 28 percent of the energy consumed by human beings. Solar energy is now widely used in the production of electricity. Solar Collectors are used in aluminum, copper, steel and coated materials. Solar rays have a great importance today when heating water. In 2010, the solar thermal power output reached $1 \mathrm{GW}$. Most developing countries use thermal energy. With these devices, he produced electricity at night by means of natural gas. Solar collectors can cook food. Temperature in the collector's focus will be reached. Such kitchen appliances can be widely used in developing countries. Many countries use wood for cooking. As a result, many woods disappear. For example, a biomass lost in India in the first year is 68 million tons of $\mathrm{CO}_{2}$ emissions into the atmosphere. Solar collectors play an important role in reducing emissions to the atmosphere. The use of solar energy in the chemical industry has led to the use of oxidized zinc production technology by the Solar Beads in 2005. At the top of the sun, zinc oxide can be extracted from the net by $1200^{\circ} \mathrm{C}$ using pure zinc. Subsequently, the addition of the zinc to the water results in the formation of a chemical reaction that results in the release of hydrogen. Hydrogen is used as a power generation or as a fuel.

\section{Materials and Methods}

Solar Transport Photoelements can be installed on different types of transport. For example: in ships, electromobiles, airplanes and dragons. The energy produced by photovoltaic elements is widely used in electric motors. In addition, photovoltaic elements are installed in polard, and these elements produce the energy needed to operate the air conditioner, light and emergency system. Solar-powered planes provide 24-hour flight in the air. Thanks to these systems Earth's satellites have long been employed.

As a result of light rays passing through the atmosphere, the water absorbed by the water layer is $1020 \mathrm{wt} / \mathrm{m}^{2}$. It should be noted that the flow of light passing through the surface within one day varies by day and night change.

Solar Energy and Heat Transfer Methods.

1) Electricity generation through photovoltaic.

2) Turning solar energy into heat by means of heaters.

3) Geliotermic energy.

4) Termohavo Power Station

5) Solar aerostatic power station.

Useful side and shortcomings:

1) Completeness and publicity of the source.

2) The environment is harmless and useful.

Disadvantage:

1) The temperature dependence of the day temperature on flour flour.

2) Always need to accumulate.

3) Cost of the device.

4) Always clean the light-emitting surface.

5) Construction of the atmosphere around the power plant. [4].

In ancient times, people thought deeply about the use of solar energy. According to legends, the Greek philosopher Archimedes lost the enemy's ships with mirrors. 1 - Solar heater was created by Frenchman J. Weifson. He made a large bumpy bottle and set the sun rays at 1 fountain. This device is located at an altitude of $68 \mathrm{~m}$ above the ground, burning dry ground. Later, Swedish scientist N. Sossyur created a water heater. The water in the pot of this appliance has dried up to $88^{\circ} \mathrm{C}$. In 1774 , French scientist A. Lauaze discovered the solar thermal energy concentration for the first time. Soon the UK has a very large dual-lens lens oriented, which lasts for 3 seconds and diluted the granite.

\section{Discussion}

The first solar panels were created in France and adapted to convert solar energy into mechanical energy. At the end of the 11th century at the Paris exhibition, the hardware was presented by O. Musho. By means of the built-in mirrors, the rays focus on the foci. A Modern Solitaire Battery Device was Created In 1953, The principle of operation of this device was to convert solar energy into electricity.

Solar panels are being constructed to create artificial sunlight, with high artificial high temperatures based on many experiments and technologies. 
a. QES industry was created in 1985 in Crimea. Its capacity was 5 MW. For just over 10 years, it's just 2 million $\mathrm{kWh}$, which is very expensive and has shut it down in the 1990s.

b. Solar energy can be used without turning it into electricity in everyday life. For example, when lighting the room, heating water. Solar collector for heat collecting, scavenging and storage. In these collectors water can be heated up to $60-900{ }^{\circ} \mathrm{C}$, which reduces the utility fees to $50-70 \%$.

c. One of the complex systems created by America is the solar system for Heat Experiments. The system is tested for heat resistance of the outer layers of the missile.

d. In 2008, 274 MW solar tacks were installed in Korea.

e. Japan has a power output of $3 \mathrm{GW}$. In Germany, the installed capacity of the QES is $5 \mathrm{GW}$.

Principles of solar panels Operation of semiconductor photofrequency devices in the conversion of solar energy into electric power is now a major task. Because semiconductors provide one-step straight-through energy. A photovoltaic effect is used to generate energy in a semiconductor photovoltaic. This phenomenon occurs when nonhomogeneous semiconductors are exposed to the solar radiation. Photovoltaic effect was discovered in 1839 by French physicist Edmond Beckerelle. Edmon experimented with two electrodes and an electrolyte battery that detected that some of the materials have the ability to produce electricity in the light.

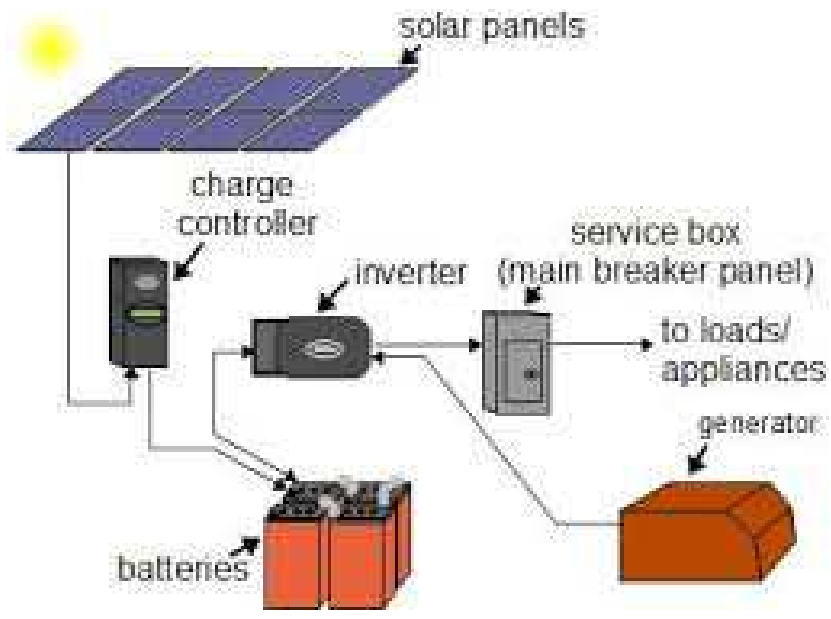

Figure 2. Production process from solar panels [5].

How does this happen?

It must be said that the solar light contains a certain amount of energy. Since the wavelength of light is not the same, we see this variety in different colors. Once the light receiving reaches one layer of the semiconductor, light emits its energy to the electrons, so that the moving electron leaves the orbit. The movement of the electrons that emerge is indicative of the electric current. But 40 years have passed since the creation of the first solar panels. In 1883, the Charlie Fritz semi-conductor was covered with a very thin layer of gold and created a solar cell. The battery of this battery does not exceed $1 \%$. Similarly, modern photovoltaic elements were palned by the 1946 Ressell Oval campaign. Earth satellites, equipped with the first photovoltaic elements, were launched in 1957. After that, the power supply of geostationary satellites began to be supplied by solar batteries. Since 2000, the manufacturing industry of silicon mono and polycrystalline elements has reached a very high level. The industry of solar ecosystems has also been found. Currently, the most commonly used mono and polycrystalline silicon has 87 percent of the world market, 5 percent of amorphous silicon and 4, 7 percent for cadmiumtellurizing. The basis for the production of solar photoelectric panels is silicon.

\section{Result}

Photoelectric effect. Photovoltaic effect of the case studying electron capture from the substance under the influence of light. This incident was discovered by G. Gers in 1887. In his experience, Gers proved that the effect of photoelectric effect is associated with 2-degree ultraviolet radiation. In 1889, D. Thompson and F. Lenard discovered that when the metal in the vacuum was exposed to light, they had the ability to emit electrons. By continuing the experiment, Lenard discovered that the number of electrons in 1 second of the metal surface was equal to the bright intensity. The energy of the electrons depends on the wavelength of light, that is its spectrum. Under certain conditions, the photofectivity phenomenon occurs in gases and atoms of the atoms. in this case, the photons will generate metamorphoses by releasing protons orbits with great energy.

\section{Conclusion}

Solar cell currently, the creation of various energies has become an actual topic. We have the information that the reserves of energy sources are usually over 50 years later. So human beings are looking for ways to obtain energy in a new way, as is the case with solar energy from the sun's rays. So, we use the solar energy effectively, and we must say that the energy sources in the Earth are caused by the sun's rays.

Raw material used for the manufacture of solar cells. Silicon is used as the main ingredient in solar cells production. $1 / 4$ of the Earth's surface consists of silicon, but it is difficult to distinguish true silicon from the calcium $\mathrm{SO}_{2}$.

How to Make a Solar Battery. A typical solar panels are photovoltaic photovoltaic modules and photocells. In contrast to solar panels, solar panels are used for solar collectors to generate electricity from electricity. The following raw materials are needed to create a solar cell.

\section{References}

[1] Sergio Daher, Jurgen Schmid and Fernando L. M Antunes, "Multilevel Inverter Topologies for Stand-Alone PV Systems" IEEE Transactions on Industrial Electronics. Vol. 55, No. 7, July 2008 . 
[2] J. Surya Kumari and Ch. Sai Babu "Mathematical Modeling and Simulation of Photovoltaic Cell using Matlab-Simulink Environment" International Journal of Electrical and Computer Engineering (IJECE) Vol. 2, No. 1, February 2012, pp. 26 34 ISSN: 2088-8708.

[3] J. A. Gow and C. D. Manning, Development of a photovoltaic array model for use in power-electronics simulation studies, IEE Proceedings - Electric Power Applications, 146 (1999), 193-200.

[4] E. I. Ortiz-Rivera and F. Z. Peng, Analytical model for a photovoltaic module using the electrical characteristics provided by the manufacturer data sheet, in 36th IEEE Power Electronics Specialists Conference (PESC '05), Recife, Brazil, 2005, 2087-2091.

[5] V. P. Sethi, K. Sumathy, S. Yuvarajan, and D. S. Pal "Mathematical Model for Computing Maximum Power Output of a PV Solar Module and Experimental Validation" Ashdin Publishing Journal of Fundamentals of Renewable Energy and Applications Vol. 2 (2012), Article ID R120312, 5 pages doi: $10.4303 /$ jfrea/R120312.

[6] Hiren Patel and Vivek Agarwal, "MATLAB-Based Modeling to Study the Effects of Partial Shading on PV Array Characteristics", IEEE TRANSACTIONS ON ENERGY CONVERSION, VOL 23, NO 1, MARCH 2008.

[7] European Photovoltaic Industry Association. Global Market Outlook for Photovoltaic's Until 2016 May 2012. P. 11.

[8] F. Nayan, M. Islam and S. Mahmud, "Feasibility Study of Smart Grid in Bangladesh", Energy and Power Engineering, Vol. 5 No. 4B, 2013, pp. 1531-1535. doi: 10.4236/epe.2013.54B290.

[9] T. Hasan, M. F. Nayan, M. A. Iqbal, M. Islam, "Smart Solar Home System with Safety Device Low Voltage Alert", UKSim $14^{\text {th }}$ International Conference on Modelling and Simulation, Pages 201-204, ISBN: 978-0-7695-4682-7.

[10] R. Bhol, A. Pradhan, "Environmental Effect Assessment On
Performance of Solar Pv Panel”, 2015 International Conference On Circuit, Power And Computing Technologies [ICCPCT].

[11] V. Khanna, B. K. Das, D. Bisht, "Matlab/Simelectronics Models Based Study Of Solar Cells", International Journal Of Renewable Energy Research, Vol. 3, No. 1, 2013.

[12] M. A. Islam, N. Mohammad, P. K. S. Khan, "Modeling and Performance Analysis of a Generalized Photovoltaic Array in Matlab", Proceedings of 29th annual IEEE Power Electronics Specialists Conference, vol. 1, pp. 86-93, 1998.

[13] S. Hegedus, and A. Luque, Achievements and Challenges of Solar Electricity from Photovoltaics. Handbook of Photovoltaic Science and Engineering (Second edition). p. 45.

[14] European photovoltaic industry association. Solar generation 6: solar photovoltaic electricity empowering the world, 2011. p. 10.

[15] M. Bouzguenda, T. Salmi, A. Gastli and A. Masmoudi, "Evaluating Solar Photovoltaic System Performance using MATLAB", 2012 First International Conference on Renewable Energies and Vehicular Technology in IEEE.

[16] R. Krishan, Y. Raj Sood, B. U. Kumar, "The Simulation and Design for Analysis of Photovoltaic System Based on MATLAB" 2013 International Conference on Energy Efficient Technologies for Sustainability (ICEETS, IEEE 2013, 978-14673-6150-7).

[17] T. Salmi, M. Bouzguenda, A. Gastli, A. Masmoudi, "MATLAB/Simulink Based Modelling of Solar Photovoltaic Cell”, International Journal Of Renewable Energy Research, Vol. 2, No. 2, 2012.

[18] D. Bonkoungou, Z. Koalaga, D. Njomo, "Modelling and Simulation of photovoltaic module considering single-diode equivalent circuit model in MATLAB", International Journal of Emerging Technology and Advanced Engineering, Volume 3, Issue 3, March 2013. 